\title{
the paradox of philosophy for children and how to resolve it
}

\author{
maria kasmirli \\ university of sheffield, united kingdom \\ orcid id: https:/ / orcid.org/0000-0001-8176-6945
}

\section{abstract}

There is a paradox implicit in the idea of philosophy for children (P4C). Good teaching starts from the concrete and particular, and it engages with each student's individual interests, beliefs, and experiences. Preadolescents (and to some extent everyone) find this approach more natural than a more impersonal one and respond better to it. But doing philosophy involves focusing on the abstract and general and sometimes disengaging oneself from one's personal interests and beliefs, in order to reason from the perspective of others. It involves critiquing one's own attitudes, recognizing abstract relations, and applying general principles of reasoning. So, if, broadly speaking, good teaching focuses on the concrete and personal, and good philosophy on the abstract and general, how can there be good teaching of philosophy to children? I call this the paradox of philosophy for children, and in this paper, I explore how teachers should respond to it. Should they sacrifice good teaching practice, adopting a heavily teacher-centred approach in order to correct their students' natural biases? Should they lower their expectations of what philosophical skills children can acquire? Should they even attempt to teach philosophy to children? The paper will argue that there is a better option, which draws on children's imaginative abilities. The core idea is that by encouraging children to identify imaginatively with other perspectives, we can use their natural focus on the concrete and particular to help them adopt more abstract, critical ways of thinking. In this way, their focus on the concrete and personal can be the very means to get them to think more abstractly and critically. The paper will go on to outline a general strategy for implementing this approach, the Scenario-Identification-Reflection (SIR) method, which will be illustrated with examples drawn from the author's own classroom practice. The paper will also respond to several objections to the proposed strategy and offer some general reflections on the SIR method.

keywords: philosophy for children (p4c); student-centred learning; imagination; sir method.

resumo

\section{o paradoxo da filosofia para crianças e como resolvê-lo}

Existe um paradoxo na ideia de filosofia para crianças (P4C). O bom ensino começa do concreto e do particular e envolve os interesses, crenças e experiências individuais de cada aluno. Os pré-adolescentes (e até certo ponto todos) acham essa abordagem mais natural que outra mais impessoal e respondem melhor a ela. Mas fazer filosofia envolve focar no abstrato e no geral e, algumas vezes, se desapegar dos interesses e crenças pessoais de alguém para raciocinar a partir da perspectiva de outros. Envolve criticar as atitudes, ver relações abstratas e aplicar princípios gerais. Portanto, se, em termos gerais, o bom ensino se concentra no concreto e no pessoal, e a boa filosofia no abstrato e no geral, como pode haver um bom ensino de filosofia para as crianças? Eu chamo isso de paradoxo da filosofia para crianças e, neste artigo, exploro como os professores devem responder a ele. Deveriam sacrificar as boas práticas de ensino, adotando uma abordagem fortemente centrada no

1 E-mail: m.kasmirli@gmail.com 
professor, a fim de corrigir os preconceitos naturais de seus alunos? Deveriam diminuir suas expectativas sobre quais habilidades filosóficas as crianças podem adquirir? Mais ainda: deveriam sequer tentar ensinar filosofia às crianças? $\mathrm{O}$ artigo argumentará que existe uma opção melhor, que se baseia nas habilidades imaginativas das crianças. A ideia central é que, incentivando as crianças a se identificarem imaginativamente com outras perspectivas, podemos usar seu foco natural no concreto e no particular para ajudá-las a adotar maneiras de pensar mais abstratas e críticas. Dessa maneira, seu foco no concreto e no pessoal pode ser o meio exato para fazê-las pensar de maneira mais abstrata e crítica. $\mathrm{O}$ artigo continuará delineando uma estratégia geral para implementar essa abordagem, o método Cenário-Identificação-Reflexão (SIR), que será ilustrado com exemplos extraídos da própria prática em sala de aula da autora. $\mathrm{O}$ artigo também responderá a algumas objeções à estratégia proposta e oferecerá algumas reflexões gerais sobre o método SIR.

palavras-chave: filosofia para crianças $(\mathrm{p} 4 \mathrm{c})$; aprendizagem centrada no aluno; imaginação; método sir.

\section{la paradoja de la filosofía para los niños y cómo resolverla}

resumen

Hay una paradoja en la idea de filosofía para niños (P4C). La buena enseñanza comienza desde lo concreto y lo particular, y se relaciona con los intereses, creencias y experiencias individuales de cada estudiante. Los preadolescentes ( $\mathrm{y}$ en cierta medida todos) encuentran este enfoque más natural que uno más impersonal y responden mejor a él. Pero hacer filosofía implica enfocarse en lo abstracto y general y, a veces, desconectarse de los intereses y creencias personales para razonar desde la perspectiva de los demás. Implica criticar las actitudes de uno, ver relaciones abstractas y aplicar principios generales. Entonces, si, en términos generales, la buena enseñanza se enfoca en lo concreto y lo personal, y la buena filosofía en lo abstracto y general, ¿cómo puede haber una buena enseñanza de filosofía para niños? Llamo a esto la paradoja de la filosofía para niños, y en este artículo, exploro cómo los maestros deben responder a ella. ¿Deberían sacrificar las buenas prácticas de enseñanza, adoptando un enfoque fuertemente centrado en el maestro para corregir los prejuicios naturales de sus alumnos? ¿Deberían reducir sus expectativas sobre las habilidades filosóficas que los niños pueden adquirir? ¿Deberían incluso intentar enseñar filosofía a los niños? Este texto argumentará que existe una mejor opción, que se basa en las habilidades imaginativas de los niños. La idea central es que al alentar a los niños a identificarse imaginativamente con otras perspectivas, podemos usar su enfoque natural en lo concreto y particular para ayudarlos a adoptar formas de pensamiento más abstractas y críticas. De esta manera, su enfoque en lo concreto y personal puede ser el medio para lograr que piensen de manera más abstracta y crítica. El texto continuará describiendo una estrategia general para implementar este enfoque, el método Escenario-Identificación-Reflexión (SIR), que se ilustrará con ejemplos extraídos de la práctica en el aula de la autora. El texto también responderá a algunas objeciones a la estrategia propuesta y ofrecerá algunas reflexiones generales sobre el método SIR.

palabras clave: filosofía para niños (p4c); aprendizaje centrado en el alumno; imaginación; método sir. 
The paradox of philosophy for children and how to resolve it

[Mr Gradgrind:] 'Now, what I want is, Facts. Teach these boys and girls nothing but Facts. Facts alone are wanted in life. Plant nothing else, and root out everything else. You can only form the minds of reasoning animals upon Facts: nothing else will ever be of any service to them.'

-- Charles Dickens, Hard Times $(1854,3)$

\section{1. introduction}

Mr Gradgrind was wrong. Facts, and reasoning about facts, are not enough. Among other things, imagination (what Mr Gradgrind called "fancy") plays a crucial role in the education of children-especially, I shall argue, in the teaching of philosophy to children. This may seem counterintuitive. Some would say that philosophy is one of the few areas where Mr Gradgrind was broadly right - where reason, analysis, and dispassionate argument are everything. I shall argue otherwise: there is a paradox in the very idea of teaching philosophy to children, and the best way to resolve it is to draw on children's imaginative abilities.

This paper is structured as follows: Section 2 sets out the paradox I mentioned, Section 3 considers some unsatisfactory responses to it, Section 4 explains the imagination-centred approach that I favour, Section 5 describes a variety of specific classroom exercises which employ this technique, and Section 6 outlines some objections to the proposed approach and responds to them.

This is a paper about educational practice, not theory, and it is informed by many years of practical classroom experience. No doubt the ideas presented could be set within a larger theoretical framework, but I shall not attempt this here. Moreover, I do not claim that the ideas and proposals are wholly novel. I am sure that all teachers of philosophy with children have encountered the paradox in their practice and that all successful ones make use of strategies not unlike the ones I propose. My aim here is to make the paradox explicit and set out a structured framework for resolving it.

\section{2. the paradox of philosophy for children}


the paradox of philosophy for children and how to resolve it

The Philosophy for Children (P4C) movement, founded by Matthew Lipman in the 1970s, has been very successful. There are now numerous organizations involved in providing specialist philosophy teaching both to high school children and to younger, pre-adolescent children, with beneficial results (Sapere n.d.). In this context "philosophy" usually means philosophical skills rather than knowledge of specific philosophical traditions and theories. The aim of $\mathrm{P} 4 \mathrm{C}$ is, essentially, to develop children's reflective and analytic abilities - the ability to see and understand multiple perspectives on the same problem, to construct and evaluate rational arguments, to think up counterexamples and thought experiments, to articulate general principles underlying particular intuitions, and so on. More generally, the aim is to help children deal with everyday problems in a more constructive, open-minded, and thoughtful way and to give them the power to expose specious arguments and to escape the constraints of their own biases and prejudices. The hope is that philosophy will help children develop into clear, independent, and free thinkers who can contribute constructively to democratic discussions. Few would deny that these are desirable aims, and the value of philosophy for children is increasingly recognised by educational theorists and policy makers. Increasingly, too, there are moves to teach philosophy to younger, preadolescent children.2

For all this, there is a paradox at the heart of teaching philosophy to children, especially preadolescent ones. It is this. Good teaching with preadolescents is student-centred (Attard et al. 2010): it starts from the concrete and particular, and it engages with the child's individual interests, beliefs, and experiences. For example, the maths teacher makes maths problems concrete by appealing to calculations the child may do in buying sweets or playing their favourite sport, the history teacher makes connections with the child's own family experiences, and the science teacher conducts experiments with familiar, everyday objects. The aim is always to use what the children themselves bring to the classroom.

2 For example, Schola Europaea, which manages a network of schools for the European Commission and runs its own European Baccalaureate programme, makes ethics classes (which can include a substantial component of philosophical skills) compulsory from the first grade (six-year olds) onwards (Schola Europaea n.d.). 
Preadolescents find this approach much more natural than a more impersonal one and respond much better to it (Çubukçu 2012).

But doing philosophy can be in tension with this approach. It involves focusing on the abstract and general, and, at least temporarily, disengaging oneself from one's individual interests and beliefs. I am not suggesting that philosophy must be done in the formal, adversarial style that has been dominant within much of the Anglo-American analytic tradition. That style has been rightly criticised for limiting the topics that are addressed and the methods of reasoning about them, and for making it harder for some communities to participate in philosophy (e.g., Mansbridge 1990; Moulton 1983; Sherwin 1988). Critics argue that P4C-and philosophy generally - should adopt a dialogic, deliberative style instead (Field 1995, 1997; Lipman 1991; Splitter 1991). I thoroughly agree with this critique of adversarial philosophy. The tension that I want to highlight is a deeper one, which concerns the aims of philosophical dialogue itself. For as teachers of philosophy, we want to help students to step outside their own perspective. We want to help them to critique their own attitudes and assumptions, to grasp the epistemological, ontological and ethical relations underlying specific examples, and to articulate theories and arguments rather than personal associations and individual experiences. The philosophy teacher must help the child to think about other perspectives, other experiences, other ways of looking at the world. They must enable children to see the limitations of their own perspective, to recognise their own biases and prejudices, and to appreciate the power and value of counterexamples and counterarguments. In this sense, it involves de-centring the student - helping them see the world from a wider perspective.

Of course, this isn't to deny the child's individuality - far from it. The aim is that by taking this broader, more reflective perspective, the child will come to engage with the world in a more constructive way. By questioning their unthinking assumptions and looking beyond their immediate horizons, they will adopt fairer and more reliable beliefs, which enable them to become more effective and successful citizens. The de-centring will be empowering. 
So, we have a paradox (not a logical paradox but a tension that needs resolving): If good preadolescent teaching focuses on specific cases and personal associations, and good philosophy focuses on general principles and reasoned argument, how can there be good teaching of philosophy to preadolescents? I call this the paradox of philosophy for children. Again, I'm not suggesting that this paradox is a new discovery. I am sure that all teachers of philosophy for children appreciate it, at least implicitly. But I think it is useful to make it explicit and to explicitly consider how best to address it. I turn to this now. I shall begin by considering some responses that are, for various reasons, unsatisfactory.

\section{3. some responses to the paradox}

\section{1 the pessimistic approach}

One response to the paradox is to deny that we can usefully teach philosophy to preadolescent children. This view used to be widespread, influenced in part by the work of Jean Piaget (Piaget 1933). Until adolescence, Piaget held, children do not move beyond a "concrete operational" level of cognitive development. They may be able to think logically but only about concrete events. It is only when they reach the later "formal operational" stage at 12 or older that they become capable of the kind of abstract thinking required for philosophy.

There is now a good deal of evidence that Piaget underestimated the cognitive abilities of preadolescent children (e.g., Astington 1993; Gopnik 2009), and few contemporary developmental psychologists accept that young children are incapable of abstract thought. However, this doesn't resolve the paradox. The paradox does not depend on the claim that preadolescents cannot think philosophically, but on the claim that they do not find it easy and prefer a concrete, personal approach. And there is good reason to think that this is true. For one thing, psychological studies of human reasoning have shown the prevalence of certain systematic cognitive biases (for a survey, see Pohl 2004). In particular, humans are prone to confirmation bias - to seeking evidence in favour of their existing beliefs and discounting evidence that tells against them (see, e.g., Oswald 
and Grosjean 2004). Indeed, it has been argued that the function of human reasoning is precisely to generate arguments in support of one's beliefs, for use in public argumentation (Mercier and Sperber 2011.) This does not mean that people cannot reflect on the truth of their own beliefs and reason in line with rational norms, but it does mean that doing so will be a slow, effortful process, which involves correcting for one's instinctive cognitive biases (Kahneman 2011). Such a process will be especially difficult for young children.

\section{2 the teacher-centred approach}

If philosophical thinking is hard for children, then perhaps teaching it requires the adoption of a teacher-centred approach, in which the teacher corrects the students' natural tendency to focus on the concrete and personal and explicitly instructs them in the principles of critical and abstract thinking? I am not sure that anyone currently advocates this view. The philosophy for children movement is a relatively recent one, which has developed hand-in-hand with student-centred learning methods. It would certainly be out of step with modern teaching practice, and while it remains a possible strategy, it would have serious drawbacks. Good teaching should be fun, stimulating, and engaging, and it should make children enthusiastic about the subject. The teacher-centred approach is unlikely to have these effects, even if it managed to instil the desired skills. Moreover, it would be likely to work only with a select few students, who are highly motivated and wellsupported.3 It is not likely to work well with children who are poorly supported outside the classroom or who have problems with focus or motivation. If the aim of teaching philosophy to children is to empower children of all backgrounds and help create a democratic culture in which all individuals can participate equally, then it is vital that the methods used should be ones that work for all students. The teacher-centred approach, by contrast, is likely to put many children off philosophy - especially, perhaps, those who could most benefit from it.

3 An extreme example of the teacher-centred approach is the rigorous philosophical education of the young John Stuart Mill, organised by his philosopher father James (the model for Dickens's Mr Gradgrind). Though this was successful in inculcating the skills, it had negative aspects and led to Mill's experiencing a "mental crisis" in young adulthood (Mill 1873). 
the paradox of philosophy for children and how to resolve it

\section{3 the pre-philosophy approach}

Another response would be to adopt a less ambitious, more selective approach to doing philosophy with children. Of course, as I explained earlier, P4C is already selective in one way. It is not concerned with conveying detailed knowledge of philosophical theories and traditions and focuses instead on training in philosophical skills. But the paradox of philosophy for children presents a challenge even - in fact, especially - to such skills-based teaching, since the skills involved are hard to teach in a student-centred way.

The suggestion I am considering here is that we should be selective in another way. It is that we should not expect preadolescent children to discuss issues in a genuinely reflective way, critiquing their own beliefs and assumptions and grasping the general principles that underlie their disagreements. Rather (the suggestion goes), we should focus on more basic, less demanding skills. We should encourage students to express their personal views, to accept criticism calmly, to defend their views with arguments, to listen patiently to the views of others, and to make critical points in a respectful and courteous fashion. We can think of this as a preparation for full-blown philosophical discussion - "prephilosophy" we might call it. This approach to P4C prioritizes good teaching and focuses on the development of basic skills.

Much that goes on in P4C sessions takes the form of such pre-philosophy, and I do not mean to deny the value of it. Knowing the etiquette of dialogue and displaying the appropriate interpersonal attitudes (patience, respect, courtesy, and charity) are important philosophical skills in themselves (and ones that not all professional philosophers have fully mastered!). Moreover, children enjoy this activity, and it gets them excited about philosophy.

It does have a downside, however, and even risks. There is a danger of the approach becoming formulaic and unchallenging. Students may be presented with a question and encouraged to express and defend their responses to it, but there may be little attempt to criticize and evaluate their views. And students may be told that "there are no right or wrong answers" - interpreted as meaning that all 
answers are equally good. Of course, the motive behind this approach and motto is good. It is to give students confidence to express themselves and to contribute to the discussion. These are valuable elements of pre-philosophy. But the risk is that the students will get the idea that this is all there is to philosophy-that philosophical debate is simply about expressing a view and thinking up reasons to support it and to reject rival ones (which, if Mercier and Sperber are right, is the natural function of the human reasoning system). Philosophy might even make students more fixed in their views by encouraging them to think up further reasons to hold them (Frankish 2018).

Moreover, if there is no evaluation, no progress can be made towards a resolution of whatever issue is being discussed. At the end, the class are left with a range of competing viewpoints, perhaps all the more entrenched as a result of having been publicly defended. In such an exercise, there is no mechanism for arbitrating between the different viewpoints and moving towards a resolution of the issue. The discussion becomes an adversarial debate rather than a dialogue-a game in which everyone displays their ingenuity, but where there is little genuine engagement and reflection and no progress on the problem itself.

It might be objected that this is inevitable. Arguably, progress is not possible in philosophy (Dietrich 2011). Perhaps all we can do is articulate the various possible positions, make the costs and benefits of each explicit, and then make an informed choice of where to stand. This may be the case in some areas of philosophy, but I don't think it is a good model to adopt in P4C - at least if our aim is to equip children with the skills needed to take a constructive part in democratic discussions. For such discussions have a practical role. They centre on issues that need to be resolved (at least for the time being; in a democracy, decisions can always be reconsidered). Of course, the resolution may be by vote, with the majority view prevailing, but that need not (and should not) exclude other attempts at resolution, which may precede voting. Sometimes, we can resolve disputes rationally by collectively evaluating the different viewpoints, arbitrating between them in a way perceived as fair and rational, and reaching a 
the paradox of philosophy for children and how to resolve it

consensus. (At any rate, this may be achievable with small-scale, local issues, if not with larger, national ones.) If such a rational consensus can be achieved, it may provide a sounder basis for decision making than simple weight of numbers.

But such rational consensus-building is possible only if individuals are prepared to reflect on their own views in an open-minded way and to change them in the light of objections. If students are to learn these skills, they need to see beyond their own individual viewpoints. Here pre-philosophy won't be enough. Respectfully hearing rival views is unlikely to effect a change of mind. The student is more likely to respond by looking for objections to the alternative positions and thinking up further arguments for their own view. How can we encourage children to be more self-critical? The pressure could come from the teacher, as a figure of authority. The teacher could review each student's contribution, highlighting inconsistencies, fallacies, and counterexamples, and suggesting revisions. But this would be to revert to a teacher-centred approach. What we really need is a way of stimulating spontaneous self-criticism and self-evaluation by the children themselves.

I think there is a way of doing this, consistently with the student-centred approach. It involves drawing on children's imaginative abilities.

\section{4. the imagination-based approach}

\section{1 the role of imagination}

Children's natural focus on the concrete and personal need not be an obstacle to getting them to think abstractly and critically. In fact, it can be the means to achieve that end. The basic idea is very simple. Children are imaginative; they like imitating, pretending, dressing up, play acting, and so on. And we can use this imaginative ability to get them to understand other perspectives and to question their own. Suppose we are exploring a certain topic-immigration, say-with a P4C class. We start by presenting the children with a scenario or story involving characters who have direct personal experience of the topic and whose perspectives on it are different from the children's own. We then invite the children to identify imaginatively with one or more of those characters, 
encouraging them to use all their ingenuity and acting skills to express the feelings and beliefs of the characters in question. (I shall say more later about techniques that can be used to achieve this.) Then, afterwards, we ask them to step back and reflect on the topic again and see if they are inclined to revise or rethink their original views.

In taking this approach, we don't need to suppress children's tendency to focus on the personal and the concrete; instead we exploit it. If we can get a child to imaginatively identify with another person's experience and situation, then their natural focus on the personal and concrete will now automatically become a focus on that person's experience and situation. If they engage in debate while inhabiting this other viewpoint, they will spontaneously produce arguments for that viewpoint and against alternative ones, including their own actual one. Thus, the very same mechanisms that formerly locked them onto their own perspective will now serve to lock them onto a very different one. Then, when they end the pretence and reflect on the topic again, they will have a vivid and sympathetic representation of a contrasting perspective on it. In this way, imagination can induce children to adopt a wider, more pluralistic, outlook and help them appreciate any weaknesses or inadequacies in their original view. In discussion, we may then be able to build on this pluralism to help the children articulate general concepts and principles which they can use to represent, explain, and even reconcile the different views.

I am suggesting, then, that in teaching philosophical skills to preadolescent children we use the children's natural focus on the concrete and personal as a way to facilitate more abstract, critical ways of thinking. Again, I am not suggesting that this proposal is new within P4C. John Dewey, whose philosophy of education inspired Lipman, held that imagination has a central role in inquiry (Bleazby 2012; Chambliss 1991). For Dewey, it is imagination that enables us to go beyond experience and frame solutions to the problems we face (Dewey 2004, 60). Imagination reconstructs experience in creative ways, and learning and reasoning involve controlled use of the imagination (Dewey 1966, 324-5). The method I 
the paradox of philosophy for children and how to resolve it

propose is firmly in this Deweyan spirit. Moreover, imagination-based strategies have always been part of P4C practice. Lipman himself produced novels for use as philosophical texts ("story-as-text"), designed to enable children to explore ideas and perspectives in a safe way, and I am sure that many P4C practitioners use role play and imaginative exercises with their classes. My aim here is simply to formalize the approach and explore ways in which it can be developed.4

\section{2 the sir method}

We can formalize the approach as a three-stage method, which I'll call the Scenario-Identification-Reflection, or SIR, method. We create a scenario, encourage students to imaginatively identify with a particular perspective within it, then invite them to reflect on the topic again in the light of this experience.

- Scenario: Create a scenario, using texts, props, artwork, etc.

- Identification: Invite students to imaginatively identify with a perspective within the scenario.

- Reflection: Encourage students to reflect on the experience of being someone else and to compare this new perspective with their own original one.

In its use of a scenario, the SIR method is in line with standard P4C practice, which typically employs a stimulus - an object designed to spark ideas about a topic. The key difference is that the purpose of the scenario in the SIR method is to facilitate an act of imaginative identification. The confrontation with the scenario does the pedagogic heavy lifting, naturally inducing the child to adopt, inhabit, and articulate a different perspective. This then provides a source of insights that the child can use in subsequent reflection, helping them to develop a more critical perspective on their own original views. Through an imagination exercise, the child comes to understand "otherness" from a first-person point of view, and this understanding then informs their thinking about the topic.

4 Socrates' tutoring of the slave boy, described in Plato's Meno, employs a related method. Socrates presents the child with specific stimuli-diagrams, prompts, questions-designed to help him think through a maths problem in a new way (supposedly recollecting prenatal knowledge). However, the process is far more teacher-centred than the one I propose. There is no imaginative identification involved, and Socrates is, in effect, guiding the boy through his own reasoning, rather than enabling him to discover a new perspective for himself. 


\section{5. implementing the sir method}

5.1 extending our sympathies

The idea behind the SIR method is that by getting children to engage imaginatively with alternative situations and experiences, we can help them to appreciate alternative perspectives on the same topic and to recognize the need for general concepts and principles that can structure their thinking about particulars in a critical way. But it is one thing to identify an ideal approach, another to implement it in the classroom. How, in practice, does one bring children from the concrete and personal to the abstract and critical?

One way would be to use existing stories, films, poems, or paintings to establish a scenario, encourage students to identify with characters represented within it ("Imagine you were the girl in the story..."), and then invite them to reflect on the issues raised by the exercise. News reports and historical accounts can be used similarly. The idea that art can serve to help us understand other perspectives is, of course, a familiar one. Indeed, some have suggested that it is the primary function of art. As the Victorian novelist George Eliot wrote:

The greatest benefit we owe to the artist, whether painter, poet, or novelist, is the extension of our sympathies [...] Art is the nearest thing to life; it is a mode of amplifying experience and extending our contact with our fellow-men beyond the bounds of our personal lot. (Eliot 1856, 54)

However, there are drawbacks to using texts and artworks in P4C, especially with young children. Such works require effort to understand and interpret, and children's attention and energy is diverted to (and sometimes exhausted by) these tasks, rather than being directed to the scenario itself. (This is especially so if the students have a range of linguistic abilities and limited experience of reading and art appreciation.) Moreover, texts require a greater effort of imagination from the children, who must imaginatively recreate the scenario in their heads as well as imaginatively identifying with the characters within it. A further problem is that it can be difficult to establish group engagement with a scenario if each student is 
approaching it individually, through personal study of a text, each forming their own interpretation of the scenario and focusing on different aspects of it. Of course, such diversity of interpretation can itself be fertile ground for philosophical discussion, but then the exercise is of a different kind from the one proposed here. Using films instead of texts can mitigate these problems somewhat, but it can be hard to find suitable material, and problems of interpretation and engagement still remain.

A better approach, I suggest, is to give the scenario a concrete realization, using props and artefacts, and to invite the children to participate by acting out a role within it. It is then, when the scenario is concrete and vivid and the child is actively engaged in it, that the SIR method works best. No special interpretative skills are needed, the children's imaginations are easily stimulated and focused, and the engagement with the scenario is a shared, social process. In the rest of this section I will outline some specific techniques I have used to implement the SIR method in my own classroom. I do not claim that these are the only, or even the best, techniques that could be used; I present them merely as examples, to illustrate the method and stimulate others to explore further ways of applying the method.

\section{2 acting it out}

The simplest way of implementing the SIR method is to have the students act out the scenario, identifying with characters within it. To create the scenario, a short dramatic play is prepared, involving conflict between characters of different backgrounds. This might be taken from a real play (I have had good results using Shylock's "Hath not a Jew eyes?" speech from Shakespeare's The Merchant of Venice), but it is often better for the teacher to write a piece tailor-made for the topic and the class. The children can also be involved in the writing, adding a further imaginative dimension to the exercise.

For the identification stage, the class are assigned parts in the play, each student being asked to play a character different in background and experience from themselves (girls may be asked to play male roles, white students to play 
black characters, and so on). (Obviously, sensitivity will be needed here; I will say more about this later.) The class members are then asked to rehearse the scene repeatedly and discuss how the parts should be acted. So far, the procedure resembles a drama class, and children generally enjoy it. But the real aim of course is not to develop students' dramatic skills, but to get them to inhabit the characters they are playing and identify with their perspectives and feelings. The rehearsal process may culminate in a performance, which might be videoed or presented to fellow students.

After the performance there is reflection in the form of a class discussion. Students are asked how it felt to play someone different from themselves, and what social and political principles a society should adopt in order to be fair to people of all backgrounds. This method can be particularly useful for promoting critical discussion of social issues, involving inequality, sexism, racism, bullying, and so on.

\section{3 multiple perspectives}

The SIR method can always be used to help children identify with their peers and gain new perspectives on real events. Here the scenario is some real incident that the class have all witnessed. It might be a playground argument or a dispute over group work in class. Each student is asked to write a report on the incident, setting out their own impression of what happened and their view of how each participant acted.

In the identification stage students swap reports. Each student is asked to study the report they have been given and then to read it out to the rest of the class, presenting it as if it were their own-thus identifying temporarily with the perspective of the writer. This identification can be strengthened by inviting other class members to challenge the reader and encouraging the reader to reply as if they were the writer. After the presentations, reports can be swapped again and the process repeated, so that each child presents multiple viewpoints.

In the reflection stage, the children discuss their responses to the exercise. Why were there so many different accounts of the same event? Were some 
the paradox of philosophy for children and how to resolve it

students lying, or were they telling the truth the best way they could? Did each person experience a different reality? Or did the same reality make a different impression on each of them? This discussion can then be extended to explore broader issues of appearance and reality, subjectivity and objectivity. Can we ever know what the world is like in itself, or can we know it only as it appears to us? (As a follow-up exercise, I sometimes place an object on the desk and get the students to describe it from different perspectives.) Can we overcome the limits of our personal perspectives and develop objective, or at least intersubjective, accounts of reality? The discussion can then turn to history and current events. Can we trust news reports and history books? Are there ways of compensating for the biases of individual observers?

\section{4 arguing for the mask}

This is a technique for helping children identify with a different argumentative perspective and facilitating critical thinking and self-criticism. Each student makes and decorates a mask. They are encouraged to make their masks distinctive and highly personalized. The class then holds a discussion session about some topic that interests them, in which each student wears their mask and expresses and defends their own view as strongly as they can. This mask-wearing discussion is the scenario.

In the identification phase, students swap masks with peers they disagreed with, and the discussion resumes. Now, each student must argue for the view of the person whose mask they are wearing, trying to defend it as if it were their own. Often, students cannot remember the arguments and responses of the original mask wearer and must think them up quickly for themselves, strengthening the identification. The masks help the children to focus on the imaginative task of adopting the distinctive argumentative persona of the person whose distinctive mask they are wearing. (I sometimes urge them to "argue for the mask".) The masks also introduce a game element, which children enjoy. They love pointing out when a fellow student has failed to argue for the "mask's view". In a variant on the scenario, a series of one-to-one discussions are held between 
pairs of masked students with opposing views, and in the identification phase there is a straight swap of masks and argumentative positions.

In the reflection session, the children discuss what it was like to argue for a view that was different from their own. Did it help them to understand that view better? Did it make them more sympathetic to it? Did it do anything to change their own view of the subject?

\section{5 only following orders}

This application of the SIR method (which is inspired by the notorious Milgram experiments) 5 involves employing two students as confederates. The exercise is a little artificial, comparable to playing the devil's advocate. It should be used with caution (see the remarks on sensitivity in the next section), but it can generate excellent discussion. The session begins with the students being asked to create drawings that express something important to them. It might be their pet, their sports team, or their family. When they have done this, they show their drawings to the class and explain their meaning. The teacher then selects two students - call them Jack and Jill-and asks them to come to the front. The class think the choice was random, but Jack and Jill are in fact confederates who have been prepared for their roles beforehand. The teacher then tells Jill to take Jack's drawing and rip it to shreds. Jack feigns distress and begs Jill not to, and Jill makes a show of reluctance, but the teacher insists that she must do it, and she eventually complies. The rest of the class are shocked, and there is comment and outcry. Here the ripping up act is the scenario, and the aim is to induce the class members to make a dual identification. They will naturally identify and sympathize with the victim, Jack. (It could easily have been their drawing instead of his.) But they may also identify with the perpetrator, Jill, wondering what they would have done if they had been chosen to do the ripping up instead of her.

After a few moments, the teacher explains that it was all a pretence. Jack and

\footnotetext{
5 These controversial experiments, which were carried out by Yale psychologist Stanley Milgram, were designed to discover how willing people would be to carry out unethical actions in obedience to an authority figure (Milgram 1963).
} 
the paradox of philosophy for children and how to resolve it

Jill were only acting, and Jack had created a drawing that he didn't mind being ripped up. The session then moves to reflection. If the scene had been real, what would we have thought about Jill's action? What kind of harm did the ripping up do to Jack? Could Jill have done something to make up for the harm? If so, would that have made everything all right? Did Jill herself do anything wrong? After all, she was only following the teacher's instructions. Should she have disobeyed? When is it OK to disobey authority? The aim is that, by building on their identification with both victim and perpetrator, the class will bring a more critical perspective to bear on these issues of harm, respect, justice, reparation, and resistance to authority.

\section{6 the most important person}

This final exercise (which is a favourite of mine) puts a spin on the SIR method by using it to get children to make a certain self-identification. It works like this. Before class, the teacher sets up a tent in the classroom and places a mirror inside. When the children arrive, the teacher explains that she has a surprise for them: They are going to meet the most important person in their lives. One by one, the children go up to the tent to meet this person. (As they are waiting, the teacher may ask them to speculate about who they will see and why that person is the most important in their lives.) The children enter the tent and see themselves. This is the scenario. Its aim is to induce the children to identify themselves as someone fitting a certain description - the most important person in their lives.

In the reflection phase, the class talk about what happened and what it meant. The discussion may span issues of confidence, responsibility, selfawareness, and personal identity. How and why might one be the most important person in one's own life? What sort of duties does a person have towards themselves? How do these differ from their duties to other people? Does one stay the same person throughout one's life? What exactly is a person anyway? This exercise can provoke some surprisingly mature reflections from young children. 


\section{7 the core of sir}

The above are only samples of exercises using the SIR method, and many more could be developed. The core of the method is the creation of a concrete scenario, designed to engage children and induce them to identify with a perspective represented within it. This identification then enables and supports a deeper, more critical engagement with philosophical issues arising from the scenario. Although I have recommended the method for use with preadolescents, it could, like other aspects of P4C, be employed with older children and adults. Again, the core idea is that the best way to stimulate reflection and critical thinking is to build on personal experience, even if only of an imaginative kind. This in turn acknowledges the fact that we are not purely rational agents but embodied creatures whose thinking is dependent on a host of evolved cognitive systems and shaped by the accidents of personal history.

\section{6. objections and replies}

The SIR method is not intended to be innovatory but rather a formalization of strategies that are, doubtless, already widely followed. It is, I think, a natural way to help children, or indeed adults, engage philosophically with moral, social, and political problems. Of course, I have not provided any concrete evidence that the method works. As I stressed earlier, this paper is based on my own classroom practice. I have found that the SIR method excites and engages children and makes it easier for them adopt a critical, reflective perspective to the topics we discuss. (The method can be particularly useful with children who may not be engaged by more traditional methods - for example, who are shy, have problems with attention, or do not find it easy to work with written texts.) But this is merely anecdotal. Experimental work will be needed in order to establish the value of the method, testing specifically for the value of imaginative identification in facilitating the development of philosophical skills. To the best of my knowledge no such work has been done, and I hope that this paper will encourage educational psychologists to pursue such investigations. For the present, I shall limit myself to responding to some objections to the SIR approach. 
the paradox of philosophy for children and how to resolve it

One worry is that the method is too structured and schematic, with its three defined phases. Should we not be more flexible, continually adapting our methods to individual students and group dynamics? Does the SIR method itself risk becoming teacher-centred? 6

These objections prompt an important clarification of the SIR method. I stated the method in a formal way to bring out the essential components - the scenario that drives the exercise, the imaginative identification that opens up the child's perspective, and the reflection that builds on this new perspective. But I do not mean to suggest that these elements must always be rigidly separated or that they must proceed in strict succession. The exercise can move backwards and forwards between the different elements, introducing spells of reflection during the early stages, for example, or breaking the reflection to return to the scenario. The three-stage structure should be thought of as a logical one, not a temporal one. It is also important that exercises are flexible, with the teacher being ready to adapt the scenarios and the children's roles within them in response to opportunities and difficulties that may arise. The method is more like scaffolding for the teacher's own creativity than a rigid prescription for lesson plans.

A second worry concerns the centrality of imagination. Do young children really have the imaginative abilities required for the SIR method to be successful? Is it too demanding to expect young children to project themselves into the minds of people with very different experiences and attitudes? And what psychological mechanisms does the process actually involve and when do they develop?

These are questions for experimental and theoretical psychologists, and I shall not attempt to address them here. The SIR method does not assume any specific account of the mechanisms of imagination and can remain neutral on that question. It does, of course, assume that children have the ability to imaginatively inhabit other perspectives, but it does not assume that they can do this spontaneously or without assistance. Indeed, the purpose of the scenario element is precisely to stimulate and scaffold their imagination. Moreover, the method

6 Thanks to Arie Kizel for raising this objection. 
does not require a deep psychological identification with another person. We might distinguish between what I shall call situational identification and psychological identification. Situational identification involves imagining yourself, with your existing experiences and attitudes, in a different situation (for example, that of an immigrant). Psychological identification involves imagining yourself possessing different experiences and attitudes. The latter is a more demanding feat and doubtless difficult for young children (and not only children). Ideally, we would like children to engage in psychological identification, but it is not essential to the method. To begin with, it is enough for them to achieve situational identification - for them to imagine themselves living in a different place, under different conditions, facing different problems, needing different things. If they do this, then it is likely that they will spontaneously start to imagine hypothetical psychological changes, too. In that situation they would have different beliefs, fears, hopes, desires, and so on. In other words, we can let the situational identification drive the psychological identification, rather than requiring the latter at the outset. The situational identification itself, of course, is driven by the concrete features of the scenario, which is itself the product of the teacher's imagination. Of course, some children will find the imaginative process easier than others. But this merely indicates the need for scenario creation to be flexible and tailored to individual students' needs.

A third worry, more practical this time, concerns the sensitivities involved in encouraging children to imaginatively adopt other identities. Issues of identity are of course extremely sensitive ones, and some children may feel uncomfortable in being encouraged to assume, even temporarily, identities other than their own. Isn't the SIR method playing with fire?7

This is a serious concern. I do not think it is an objection to the SIR method as such, which, as I have already noted, is a simple and natural technique for helping children to broaden their understanding of themselves and their world. The issue is a practical one: how can we use the method in a way that does not make 
students feel uncomfortable or cause distress? And how can we draw the line between a stimulating challenge to a child's existing perspective and the forced adoption of an uncomfortable persona? In practice, this needs to be addressed at two levels. First, before the lessons begin, the teacher must provide a clear explanation of the method to be used and its aims, adapted for each of the relevant parties (the children themselves, parents, school administrators) and obtain the consent of all parties. It must be clearly understood that no child is expected to adopt a role they feel uncomfortable with and that children can withdraw from an exercise at any point. Second, during the lessons, the teacher must employ the method with care and sensitivity and be continually ready to adapt exercises to the children's needs. This is, of course, not always easy. The very aim is to stimulate the children to push their boundaries and to question their own perspectives. The key thing is that the children should feel in control of the process and indeed enjoy it. Here again the building of the scenario is crucial. It must engage children, invite them in, make them want to explore and challenge themselves. There are no easy solutions here, and, as with all teaching strategies, the success of the method depends ultimately on the teacher's ingenuity and sensitivity in applying it.

\section{7. conclusion}

This has been a practical paper, which has drawn on the author's classroom experience and has been relatively uninformed by educational theory. There are, I think, clear links with theoretical approaches -in particular, with work on the scaffolding cognitive development (e.g., Vygotsky 1986; Wood, Bruner, and Ross 1976). Psychological work on the nature and development of imaginative abilities and the function of play-acting in childhood is also deeply relevant. I am sure that profitable connections can be made here, which may help to expand and refine the SIR method. This is work for another time, however. The present paper is addressed primarily - though not exclusively - to practitioners of P4C. My aim, in setting out the SIR framework, has been to clarify the logical structure of their work with students. My hope is that practitioners of P4C will recognize the SIR 
method as one they have often used themselves and that they will be inspired to devise new applications of the method and to share ones they are already using. I hope, too, that by highlighting the structure of P4C classes, this paper will be of use to policymakers and administrators, who need a broad understanding of the aims and methods of $\mathrm{P} 4 \mathrm{C}$ and the ethical issues the practice itself raises. Most of all, I hope it will result in more children benefitting from the empowering effects of thinking critically about their own beliefs and choices and about the structures and norms of the society in which they live. 8

\section{references}

Attard, Angele, Emma Di Iorio, Koen Geven, and Robert Santa. 2010. “Student Centred Learning: Toolkit for Students, Staff and Higher Education Institutions." Accessed October 25, 2019. https:/ / www.esu-online.org/?publication=student-centredlearning-toolkit-students-staff-higher-education-institutions

Astington, Janet W. 1993. The Child's Discovery of the Mind. Cambridge, MA: Harvard University Press.

Bleazby, Jennifer. 2012. "Dewey's Notion of Imagination in Philosophy for Children." Education and Culture, 28(2): 95-111

Chambliss, Joseph James. 1991. "John Dewey's Idea of Imagination in Philosophy and Education." The Journal of Aesthetic Education, 25(4): 43-49.

Çubukçu, Zühal. 2012. “Teachers' Evaluation of Student-Centered Learning Environments." Education, 133(1): 49-66.

Dewey, John. 1966. Lectures in the Philosophy of Education, 1896. New York: Random House. Dewey, John. 2004. Reconstruction in Philosophy. New York: Dover Publications.

Dietrich, Eric. 2011. "There is no progress in philosophy." Essays in Philosophy, 12(2): 329344.

Dickens, Charles. 1854. Hard Times for These Times. London: Bradbury and Evans.

Eliot, George. 1856. "The Natural History of German Life." Westminster Review, 66: 51-79.

Field, Terri. 1995. "Philosophy for Children and the Feminist Critique of Reason." Critical and Creative Thinking, 3(1): 9-12

Field, Terri. 1997. "Feminist Epistemology and Philosophy for Children." Thinking: The Journal of Philosophy for Children, 13(1): 17-22.

Frankish, Keith. 2018. "What Do You Really Believe? Take the Truth-Demon Test." Aeon, January 19, 2018. Accessed October 25, 2019. https:/ /aeon.co/ideas/what-do-youreally-believe-take-the-truth-demon-test

\footnotetext{
8 An earlier version of this article was presented at the conference Philosophy and Childhood: Theory and Practice, organized by the Department of Education Science and the Department of Philosophy and Communication at the University of Bologna in December 2018. My thanks to all the participants for their questions and comments, mentioning in particular Joshua Forstenzer, Sebastiano Moruzzi, and Luca Zanetti. I am also grateful to the Department of Philosophy of the University of Sheffield for funding my participation in the conference. Special thanks go to Keith Frankish for many conversations about this topic, which have helped to shape my thinking about the role of the imagination in teaching, and for detailed comments and advice on the article itself. Finally, I thank an anonymous referee for their helpful comments and suggestions, which have been incorporated into the final text.
} 
the paradox of philosophy for children and how to resolve it

Gopnik, Alison. 2009. The Philosophical Baby: What Children's Minds Tell Us About Truth, Love, and the Meaning of Life. New York: Farrar, Straus and Giroux.

Kahneman, Daniel. 2011. Thinking, Fast and Slow. New York: Farrar, Straus and Giroux. Lipman, Matthew. 1991. Thinking in Education. New York: Cambridge University Press. Mansbridge, Jane. 1990. “Democracy and Common Interests." Social Alternatives, 8(4): 2024.

Mercier, Hugo and Dan Sperber. 2011. “Why Do Humans Reason? Arguments for an Argumentative Theory." Behavioral and Brain Sciences, 34(2), 57-74.

Milgram, Stanley. 1963. "Behavioral Study of Obedience". Journal of Abnormal and Social Psychology, 67(4): 371-378.

Mill, John S. 1873. Autobiography. London: Longmans, Green, Reader, and Dyer.

Moulton, Janice. 1983. "A Paradigm of Philosophy: The Adversary Method." In Discovering Reality: Feminist Perspectives on Epistemology, Metaphysics, Methodology, Philosophy of Science, edited by Sandra Harding and Merrill B. Hintikka, 149-164. Boston: D. Reidel.

Piaget, Jean. 1933. “Children's Philosophies." In A Handbook of Child Psychology, second edition, edited Carl Murchison, 534-547. Worcester, MA: Clark University Press.

Oswald, Magrit E. and Stefan Grosjean. 2004. "Confirmation Bias." In Cognitive Illusions: A Handbook on Fallacies and Biases in Thinking, Judgement and Memory, edited by Rüdiger Pohl, 79-96. Hove: Psychology Press.

Pohl, Rüdiger F. ed. 2004. Cognitive Illusions: A Handbook on Fallacies and Biases in Thinking, Judgement and Memory. Hove: Psychology Press.

Sapere. n.d. "P4C Research.”. Accessed October 25, 2019. https:/ /www.sapere.org.uk/about-us/p4c-research.aspx.

Schola Europaea. n.d. "Syllabuses." Accessed October 25, 2019. https://www.eursc.eu/Syllabuses/Forms/Syllabuses.aspx.

Sherwin, Susan. 1988. "Philosophical Methodology and Feminist Methodology: Are They Compatible?" In Feminist Perspectives: Philosophical Essays on Method and Morals, edited by Christine Overall, Sheila Mullett \& Lorraine Code, 13-28. Toronto: University of Toronto Press.

Splitter, Laurance J. 1991. "Critical Thinking: What, Why, When and How." Educational Philosophy and Theory, 23(1): 89-109.

Vygotsky, Lev. 1986. Thought and Language. Cambridge, MA: MIT Press.

Wood, David, Jerome S. Bruner, and Gail Ross, G. 1976. “The Role of Tutoring in Problem Solving." Journal of Child Psychology and Psychiatry, 17: 89-100.

received in: 16.12 .2019

approved in: 03.01.2020 